\title{
Social Responsibility Education of Business Schools: Theoretical Connotation, Driving Mechanism and Path of Ascension
}

\author{
Jiang Pengfei \\ Business College \\ Beijing Union University \\ Beijing, China \\ E-mail: jpf0088@163.com
}

\begin{abstract}
Business schools are the cradle of business talent. Business school's social responsibility education is the starting point for corporate social responsibility education. At present, the social responsibility education of business schools still faces many problems. Therefore, breaking the social responsibility education dilemma, innovating social responsibility education path, and improving the social responsibility consciousness of business people is one of the important issues to business schools. This article is about that "what is the social responsibility of business school education" "Why do business schools carry out social responsibility education" "What are the problems with social responsibility education" "How do we carry out social responsibility education". From starting with several key issues, this paper not only analyzes the connotation, driving mechanism of social responsibility education, but puts forward the cultivation path of business schools' social responsibility education as well.
\end{abstract}

Keywords-Social Responsibility Education of Business schools; theoretical connotation; driving mechanism; path of ascension;stakeholders

\section{INTRODUCTION}

Universities play an important role in the citizen's quality education. As is known, universities are called to be on a mission to cultivate students' social responsibility. Business schools are the cradle of business talent. The social responsibility consciousness of commercial students will influence the social responsibility behavior of enterprises directly or indirectly in the future. Therefore, social responsibility education in business schools is the starting point of corporate social responsibility education. With increasing emphasis on social responsibility, enterprises and social sectors pay more attention to the social responsibility consciousness and business ethic recognition ability of business students.

At present, business schools still face many problems in social responsibility education ${ }^{[1]}$. As a result, it's necessary to break the social responsibility education dilemma, Innovating social responsibility education path and improving the social responsibility consciousness of business people is one of the important issues to business schools. This article is about that "what is the social responsibility of business school education?" "Why do business schools carry out social responsibility education?" "What are the problems with social responsibility education?" "How do we carry out social responsibility education?" From starting with several key issues, this paper not only analyzes the connotation, driving mechanism of social responsibility education, but puts forward the cultivation path of business schools' social responsibility education as well.

\section{THEORETICAL CONNOTATION OF SOCIAL RESPONSIBILITY EDUCATION OF BUSINESS SCHOOLS}

Social responsibility education begins by clarifying this fundamental question:"what is the social responsibility education of business schools". Social responsibility is an organization's responsibility to society. That is, an organization should operate and manage in a socially advantageous manner.

The social responsibility of business schools mainly includes the following four dimensions. Firstly, the basic social responsibility is the citizen's quality which must be possessed by the social citizen. Secondly, the social responsibility behavior of the business schools is based on the mission of business schools. Thirdly, the key social responsibility of business schools which should meet the expectations of stakeholders. Besides, it is the social responsibility to grow and innovate, that is, business schools should carry out innovation and entrepreneurship education, which is committed to the growth of business schools and the sustainable development of society.

All in all, social responsibility education in business schools is not a pure "task" imposed by society members, but the natural externalization of inner spiritual value and important way to realize their individual value ${ }^{[2]}$. It does play a significant role aiming to cultivate ethical business elites in a result of professional education and values education ${ }^{[3]}$.

\section{DRIVING MECHANISM OF SOCIAL RESPONSIBILITY EDUCATION OF BUSINESS SCHOOLS}

Why do business schools carry out social responsibility education? Scholars use different theories to explain the 
driving mechanism of social responsibility education of business schools from different perspectives.

\section{A. Three levels of driving force of social responsibility education}

Comprehensive analysis of relevant literature can be found that social responsibility education of business schools stems from both external stakeholder demands and internal needs including self-growth, brand promotion, and value realization. The driving force of social responsibility education includes the following three levels: value level, stakeholder level and brand level.

Firstly, it's necessary for business schools to improve the quality of responsibility education through internal growth and external growth, so as to realize the value of business schools, which is the internal cause.

Secondly, brand is the important guarantee of sustainable development of business schools. Therefore, business schools strive to increase the brand awareness of the business school and regional influence through social responsibility education.

Finally, business schools carried the expectations of stakeholders have an obligation to serve the others. Any individual or group that can influence schools' goals or any individual or group that can be affected by the organization is a stakeholder of the organization ${ }^{[4]}$. Not only the public and the government, but also universities and enterprises are key stakeholders of business schools.

\section{B. Three views on driving force of social responsibility education}

Nowadays, whether it is really necessary for Business schools to fulfill social responsibility or not has become a heatedly-discussed topic. Towards this topic, attitudes vary greatly from person to person. The author analyzes the driving mechanism of education of social responsibility from three perspectives of social capital, competitive advantage and institutional pressure.

1) View of social capital: Some scholars have analyzed the drive mechanism of social responsibility education based on social capital theory. As is shown, the essence of social responsibility education is an important part of social capital. Benefits resulting from doing social responsibility can never be over-exaggerated at all. To begin with, it does us good in that business schools can easily reduce the cost of trust in the public. Still better to come, business schools are able to form a virtuous cycle of continuous improvement by fulfilling social responsibilities. The best thing is that through social responsibility education, business schools can establish responsible brand image and win the recognition. Business Schools with good reputation can gain support from all walks of life so as to create a good external development environment and an internal access to the sustainable development ability of ascension ${ }^{[5]}$.

2) View of competitive advantage: Michael porter (2006) put forward strategic corporate social responsibility point of view. It indicates that social responsibility not the cost, but a source of opportunity, innovation and competitiveness ${ }^{[6]}$. This is especially true for organizations as business schools. A lot of famous international business schools convert the advantages of social responsibility of business schools to the scarce, heterogeneous resource by combining social responsibility idea and business mechanism, and thus enhance the competitive advantage of business schools.

3) View of institutional pressure: Social responsibility is an institutional arrangement essentially that can influence the behavior of the whole and individual to a certain extent, thus affecting the value of the organization. The development of business schools is influenced by external environment and stakeholders. Under the pressure of stakeholders, business schools shoulder heavy responsibilities to meet the needs of key stakeholders. Business schools establish a value system with original behavior practice and the expectations of the society behavior focused on social responsibility and common interests so that contributing to the growth of the business schools.

\section{DILEMMA AND ASCENSION PATH OF SOCIAL RESPONSIBILITY EDUCATION OF BUSINESS SCHOOLS}

Nowadays, Although many efforts have been made to improve Social Responsibility Education level in Business schools in china, there are still a lot of shortcomings which has aroused the attention of both cooperation and the public.

Analyze the causes of these problems, One of the most important reason why social responsibility education cannot meet the demand of cooperation and the public is that Social responsibility education form is not rich; Another very important reason is that theory education is not integrated with social practice; Last but not least important, Participation in the subjective level has its limitations.

1) Social responsibility education form is not rich: Many business schools carry out the social responsibility of education by setting up the business ethics courses. It's unable to make business students really understand the social responsibility of the rich connotation by a handful of courses merely. education mode with less extracurricular activities causes many problems such as less enlightening intelligence, less sharing experience and less innovation.

2) Theory education is not integrated with social practice: Social responsibility education should be heavily experienced. At present, theory education is out of step with practice education. Only by strengthening the practice study can business schools improve the consciousness of social responsibility of students, and make the concept of social responsibility be changed from passivity to initiative, and eventually to voluntary behavior.

3) Participation in the subjective level has its limitations: The main body of social responsibility education is professional teachers. As is known, quite a few professional college teachers lack practical experience. It may influence the teaching effect because of the restraint of professional background, the practical experience of professional teachers.

Great importance should be attached to the problems resulting from Social responsibility education in business 
schools. In the first place, it is bad that students cannot understand the real meaning of social responsibility. Still worse to come, it causes the result of education to flow in the form. The worst thing is that It not only makes students lose the interest both in knowledge about social responsibility but lowers the students' willingness to fulfill their obligations as well.

\section{ASCENSION PATH OF SOCIAL RESPONSIBILITY EDUCATION OF BUSINESS SCHOOLS}

Enough proper measures must be taken in order to get all problems as mentioned above timely solved. What tops the list should, of course, be that a complete social responsibility educational system must be constructed. Besides, the form of education should be diversified. what's more, multi-agent resources should be integrated. Last but not least important , the combination of theory and practice is necessary.

1) Embed social responsibility education into the whole education process: Education standard will be effectively improved by means of environmental impact, institutional constraint and cultural infection. Business schools should integrate social responsibility education into the development strategy and cultural construction of the college, and incorporate social responsibility into the whole process of education. A clear answer to the key questions such as "what is the social responsibility of business school education" "Why do business schools carry out social responsibility education" "What are the problems with social responsibility education" "How do we carry out social responsibility education" should be given to students.

2) Promote social responsibility education in the form of diversification: It is necessary to use a variety of means to give students a vivid, three-dimensional teaching experience such as theoretical knowledge learning, typical case analysis, expert seminar, experiential learning, role playing and scene simulation etc.

3) Carry out multi-agent social responsibility education: In this education system, stakeholders including entrepreneurs, governments, investors and the relevant public should be involved to overcome the knowledge limitation of professional teachers. Several of academic seminars and corporate practices are encouraged regularly to enrich the education content.

4) Enhance Service learning mode: Service Learning combining of academic knowledge and community compulsory work is known as the most important legacy of early 21st century higher education reform and development which cultivate students' responsibility awareness and ability. Business schools should enhance students' social responsibility by carrying out service learning through "community service learning", "mixed service learning" and "interdisciplinary service learning"[7].

\section{CONCLUSIONS}

It is high time that business schools did something to overcome the problems that social responsibility education are facing now, or in the long run, they might have to face more serious problems resulting from this practice.
On the basis of the driving mechanism of education of social responsibility from the perspective of social capital, competitive advantage and institutional pressure, leaders' values are the drivers of organizational social responsibility ${ }^{[8]}$. The social responsibility education in business schools needs top-level design, so as to integrate social responsibility into the business schools' strategy, and the development mission of business schools. A mission-oriented social responsibility system is the guarantee of the construction of the social responsibility of the business schools.

In view of the problems in the education of social responsibility in business schools, social responsibility education should be integrated into the whole process of training talents in business schools, so as to avoid fragmentation in social responsibility cultivation ${ }^{[9]}$.

From the perspective of stakeholders in business schools, business schools needs to always focus on the needs of main stakeholders, such as companies, governments, students and the public. The business school should strengthen the interaction with the above stakeholders and work hard on all human education which not only to improve the students' professional skills, but also to improve their sense of responsibility. Once students in business schools become a social responsibility executors and communicators from social responsibility recipients or learners, the business schools' social responsibility education will take a new step.

In conclusion, social responsibility education should focus on strategic thinking, top-level design and systematic management, as well as process management, innovation of content, methods and forms. More attention should be paid to the integration of theory and practice so as to improve the social responsibility influence and the brand awareness of business schools effectively.

\section{REFERENCES}

[1] Yi Kaigang. "Corporate social responsibility of business people: concept, dilemma and countermeasures,” Beijing: Education Research, 2013, vol. 33, pp. 152-157.

[2] Cao Wenze. "The traditional reference of social responsibility education ,” Beijing:Guangming Daily, April $1^{\text {st }} 2010$, vol. 5.

[3] Qi Anbang, Jiang Hui. “An empirical study on the current situation of business ethics and professional ethics in China's MBA," Tianjin: Science and management of science and technology, 2007, vol. 4, pp. 138-143.

[4] Freeman R E. Strategic Management: A Stakeholder Approach Boston:Pitman/Ballinger, 1984.

[5] Vázquez, J.L., Aza, C.L., Lanero, A. (2015). “Students’ experiences of universitiy social responsibility and perceptions of satisfaction and quality of service,”Econviews, Special edition, pp. 25-39.

[6] Porter, M.E. and Kramer, M.R. "Strategy and society the link between competitive advantage and corporate social responsibility," Boston: Harvard Business Review, 2006, vol.12 , pp. 78-92.

[7] Tracy McDonald, Social Responsibility and Sustainability: Multidisciplinary Perspectives Through Service Learning. Sterling: Stylus Publishing, 2011, pp. 11-12.

[8] Hemingway C. A, Maclagan P. W. "Managers personal values as drivers of corporate social Responsibility,” Journal of Business Ethics, 2004, vol.50, pp. 33. 
[9] Zhou Haitao, "The historical evolution of the cultivation of social responsibility in University, international experience and exploration of
China,” Beijing: Journal of Beijing Normal University (Social Science Edition), 2014, vol.1, pp. 12-17 